\title{
Public Service Dynamics in Population Administration Sector: A Study on Electronic ID Card Service in Makassar
}

\author{
Paiman Rahardjo \\ Postgraduate Program, Universitas Prof. Dr. Moestopo (Beragama), Jl. Hang Lekir I No. 8, Senayan, Jakarta 10270, Indonesia \\ Email: paiman.rahardjo@dsn.moestopo.ac.id
}

\begin{abstract}
Public services in population administration sector in Indonesia is currently facing a major challenge, i.e. to reach an integrated national population data through the e-ID Card, expected to be completed in 2017. Along with the decentralization of authority for recording and printing to the district/city, there are still barriers occurring in the field. This study aims to reveal the dynamics of the existing public service problems comprehensively through a qualitative approach and case study. The direct involvement of society in e-ID Card public service becomes crucial particularly to increase public awareness of the urgency of demographic data, including having an e-ID Card. There are two major problems in the e-ID Card public service in Makassar, i.e. 1) the issue of regional institutions; they are still weak both in terms of human resources, equipment, and the distribution and 2) public understanding is still low and people have not been responsive to demographic events. This requires the ability of local governments to respond to problems quickly and accurately. The study shows that the paradigm of New Public Services (NPS) in e-ID Card public service has been well implemented, including to encourage similar awareness of the community in interpreting the policy of demographic data integration. One of the effective efforts conducted by Makassar Municipal Government is the proactive services, picking up the ball directly in the target communities.
\end{abstract}

Keywords - population administration; electronic ID card; civil registration; decentralization; public service

\section{INTRODUCTION}

The government currently has the interest to continuously provide public services of Population Administration in an orderly, smooth and non-discriminatory manner, in accordance with the mandate of Law No. 23 of 2006 [1] concerning Population Administration as amended by Law No. 24 of 2013 [2]. In the context of public administration, the paradigm of New Public Services encourages public services to be more egalitarian and recognizes equal rights of citizens [3]. This is in line with the paradigm of population data integration through e-ID cards that promote equal rights of citizens to obtain national identity. In this context, public service of population administration must operate entirely for the interests of citizens and the establishment of democracy. This demand has a logical consequence on the obligation of the state to more-optimally give protection and recognition of the legal status of the residents on their significant demographic as well as other events. One recognition of the State to the residents is by providing an electronic identity card.

Based on Law No. 23 of 2006 [1] concerning Population Administration as amended by Act No. 24 of 2013 [2], residents are only allowed to have an e-ID card which contains their Population Identification Number (NIK). NIK is a resident identity that is unique or distinctive, single, and attached to someone who is registered as a resident of Indonesia. NIK becomes a single identity number for all matters of public services. The government organizes all public services based on NIK. To organize all public services the government should integrate the existing identification numbers and use them for public services, within 5 (five) years since the Law was passed.

In terms of public service, Denhardt in [3] asserts that the focus of public administration should be directed to establish public institutions marked by responsive governmental agencies with integrity. This has been promoted by Indonesian government by encouraging e-government as a responsive effort to serve people. President Joko Widodo has mandated e-government as a paradigm. In one of his speeches, he revealed: "A lot of bureaucratic work can be done much more efficiently by using the bureaucratic technology. The key word is to build e-government to improve public services and strengthen transparency and accountability". In his view, the government must be more responsive through establishing e-government, in which eID Card is one of its major requirements.

The number of residents in Indonesia bounden with ID cards until early 2016 reached 156.5 million. It has almost reached $85 \%$ of approximately 179.9 million inhabitants 
compulsory to have ID cards. The rest of Indonesian residents who have not made the data recording for e-ID Cards are now merely about 23 million or $15 \%$. The existence of residents whose data have not been recorded is a dynamic dimension to the problems in the field that need to be observed and be terminated. Moreover, the Government through the Ministry of Home Affairs has been targeting a wide range of issues related to the procurement of e-ID Cards for residents by the end of 2016. When it is completed then we will try the application of electronic voting (e-voting) for the election and regional simultaneous elections in 2017.

On the other hand, regions play a major role in succeeding public services for e-ID cards. This is because the authority of the printing and recording e-ID Cards has been fully restored to regions. In this case, the institutional capability of local governments in implementing their authority is very important. According to Ambar in [4] decentralization is assumed to be able to improve the efficiency of service allocatively and productively. Local Government should, therefore, be able to improve public services for e-ID cards more significantly. In fact, today there are 23 Million people whose data have not been recorded in Indonesia; this requires local governments to examine the barriers occurring in the field.

Based on these, in particular, there are barriers in the field, thus there are still many people who have not been recorded. This raises the question: how is the portrayal of the dynamics of e-ID Cards public service problems in the field. On that basis, this study aims to reveal the problems that hamper efforts in the field of public services in national population administration through integrated e-ID cards.

This research highlights on the urgency to accelerate the process of e-ID Card service in terms of integrating national population data as mandated by Law No. 23 of 2006 in which residents is allowed only to have one ID card that contains one Population Identification Number (NIK). This should be achieved in line with the issuance of the Presidential Decree No. 112 of 2013 on the fourth amendment of the Presidential Decree No. 26 of 2009, concerning the Implementation of NIK-based national ID card, in which the validity of non-electronic identity cards in Indonesia only lasts until December 31, 2014. It is also associated with the relationship pattern of central-local authorities in population administration sector that need to be synchronized in order to achieve optimal policy outputs at each governmental level.

\section{MATERIALS AND Methods}

This section presents the method and the data used.

\section{A. Proposed Method}

The study, conducted throughout 2015, uses a qualitative approach supported by quantitative approach to complement data descriptively (mix methods). The study also uses a case study approach to help answer the element of how and why within the main questions, and examine contemporary issues and the opportunity to control the events (cases) studied [5].

\section{B. Dataset}

This is done to portray best practices in a region that represent national condition. This study creates an inventory of primary and secondary data at the municipal level, particularly at the Department of Population and Civil Registration of Makassar, and several sub-districts in Makassar. In this study, primary data are analyzed for a thorough triangulation on the stakeholders in the regional government of Makassar.

Informants were selected purposively for interviews and to be involved in FGD. The informants include the element of central government (DG-Department of Population and Civil Registration and the Board of Directors below it), the element of provincial government (Head of the Bureau of Public Administration of South Sulawesi Province), the element of the municipal government (Head of Makassar's Department of Population and Civil Registration and staffs, Sub-district Head of Panakukkang and the administrative village head of Batua, Makassar), and the element of community (some heads of RW/RT).

\section{Rudimentary}

1) The Current Concept of Public Service: The paradigm of public services continues to shift and change. The view of Woodrow Wilson is considered as the beginning of public administration, becoming the foundation of Old Public Administration (OPA) paradigm in which the apparatus is seen to be present as a non-partisan professional, oriented to rationality. This view then shifted into more humanist values rather than economic rationality. This view was taken by George Frederickson, later known as the paradigm of New Public Administration (NPA), which developed in the '70s.

This view changed when privatization climbed back in the era of the $80 \mathrm{~s}$. The school of public services began to be affected by business values, where bureaucracy is seen fail in providing good public services. In this era came the paradigm of New Public Management (NPM) where public service was oriented to the community as its customer. This view is heavily influenced by the opinions of Osborne and Gaebler (reinventing government). This paradigm is widely used in Indonesia. One of its applications is the concept of Balance Score Card (BSC) and Key Performance Indicator (KPI) in various government agencies, particularly related to the budget such as the Ministry of Finance and the Financial Supervisory Agency.

In its development, the paradigm of NPM was again criticized for public service to the community cannot be equated with customers who are measured by their ability to acquire goods and services. This gave rise to the paradigm of New Public Services (NPS), heavily influenced by the views of Denhardt in [3]. In his view, the paradigm of NPS sees that the focus of public service is a society that equally has rights and obligations, as part of the country. Thus the relationship between society and the state should be voluntary. According to Denhardt in [3] "public administration should focus on their responsibility to serve and empower citizens as they manage public organizations and implement public policy." In other words, with citizens at the forefront, the emphasis should not be placed on either steering or rowing the governmental boat, but rather on building public institutions marked by integrity and responsiveness." He asserts that by placing citizens in the front row, the focus is no longer to how to control the paddle boats of government but rather to how to build public 
institutions characterized by government agencies with integrity and responsiveness. In this context, proactive services and the integrity of public officials is notably crucial to be achieved in the public service.

In the Indonesian context, the view of NPS paradigm has clearly emerged in Law No. 25 of 2009 on Public Service: listed in the explanation that the state is obliged to meet the needs of every citizen through a government system that supports the creation of public service excellence in order to meet basic needs and civil rights of every citizen for public goods, public services, and administrative services.

Law number 25 of 2009 on Public Service states that public service [6] is based on the principle of: a. public interest; b. legal certainty; c. equal rights; d. the balance of rights and obligations; e. professionalism; f. participatory; g. equal/non-discriminatory treatment; h. openness; i. accountability; j. special facilities and treatment for vulnerable groups; k. punctuality; and 1. fastness, ease, and affordability. Associated with an electronic ID card, Law No. 25 of 2009 explicitly affirms the state's role as an operator who must itself implement the ID card service. It is described in the elucidation of Article 13 paragraph 1 which states: "The handing out of some tasks is the provision of some tasks to others of the entire tasks of implementing services, except that by law must be carried out solely by the Operator, e.g. ID cards, driver's license, passport, certificate of land and other licensing services."

2) The Concept of Population Administration and Residents' Identity: Population Administration is not a new thing; the recording of population data was first conducted on households and individuals in the second century BC in China during the Han Dynasty [7]. Population administration was then conducted by Priests in Northern Europe, especially for the purpose of parish records in Sweden and Finland. Administration for a broader purpose began during French Revolution when the local administrators were commissioned to manage demographic data in accordance to the jurisdictional territory, including name, family name, place of birth, last domicile, employment, and a few other things. Particularly for the incidence of birth, we currently know it by the term civil registration.

The process of population census is gradually growing not just about birth, death, marriage, or divorce but also the address and migration data. The process of updating the data is constantly running to obtain precise and accurate information about each individual. Eventually, the demographic data becomes an appropriate portrayal of the population situation information. It is as described by Poulain and Herm in [8]:

- In a population register, the individual units are actual people and updating involves all the administrative information concerning them. Usually, the individuals concerned are those administratively resident in a given territory, municipality, region or country. Their data are updated for births, deaths, marriages and divorces, and also for changes of address and migration. It is the continuous nature of the updating, including that of the individual's usual address, that is the specific characteristic of a population register and its major advantage for producing demographic statistics.

With such information, the results of population census will provide overall data that can serve as policy monitoring tools as well as databases in public policy making. This was re-affirmed by Poulain and Herm in [5]:

- The main purpose of a population register is to obtain a precise identification of each individual. It also provides aggregate data about the entire population concerned, making it possible to implement and monitor a wide range of public management and planning policies. The population register is also useful for statistical purposes: it can be used to estimate the size of a population and its sociodemographic structure at a point in time, as well as population change and its various components. Furthermore, if the system is fully operational for the continuous recording of changes of address, it is the main source of data on migration.

Population administration according to the UN [9] is defined as a method of Civil Registration, i.e. a continuous, permanent and compulsory recording about significant events and their characteristics, as established through regulations in accordance with legal requirements in each country. Furthermore, the Civil Registration system is the overall Population Administration, the legal framework, institutions, including personnel record network, procedures, storage, and retrieval of data, certificate issuance, output (documents/information issued by the registry office).

What is outlined by the United Nations has been accommodated in Law No. 23 of 2006 [1], in which Civil Registry is one of the sub-systems of the Population Administration. The definition of Population Administration by Law No. 23 of 2003 as amended by Law No. 24 of 2013 concerning the population administration is a series of planning and control activities in the issuance of documents and demographic data through the Population Registry, Civil Registration, information management of Population Administration, as well as the utilization of the results for public services and the development of other sectors [10].

One concrete manifestation of population administration is residents' identity. Every organization needs a formal identity identification system for all citizens. According to Clarke [11], this formal identity is aimed at making the proper scheme of integrity, preventing falsification of data, improving the quality of continuous insurance, and preventing constraints of being anonymous or unnamed for every citizen.

The crucial role of residents' identity is very clear. According to Poulain and Herm in [8] that a centralized residents' identification allows residents' movement to be continuously monitored by correlating the changes in the population number with the turnover current. The status of a population and its socio-demographic structure can be determined at any time, without having to wait after the census. Changes in the population can be estimated at any time and not only annually as it used to be done prior to the era of computerization where citizen identification is done only locally. Centralized data can be used to give a picture of 
the status of the population and the changes occurring in each area at the same time, in a standardized and consistent manner.

Viewed from the cycle of life, the National Identity is required by every citizen without exception. From early to elderly age, national identity of residents is required to completely provide individual information according to the cycle of life of residents. According to Rajanish and Bajaj in [12] such information include, among others:

- Birth: when the baby is born, the process of identity begins. National identity is issued for the child may obtain birth certificates, registering his/her name, etc. In Indonesia, in this process, an individual will acquire NIK.

- Medical Information \& Facilities: If the system of national population data integration has been done then the identity card will be able to provide medical service information needed by the child, and the child's medical track record will be provided early. This will make easier health facility and financing. In the context of Indonesia will be the basis of Health BPJS including the Card of Healthy Indonesia.

- Investment for Child Development and Future: national identity would be beneficial to guarantee the education of children. In the Indonesian context, it is associated with the free educational assistance including the Card of Smart Indonesia. In fact, it would be beneficial up to universities including to get national scholarships like LPDP and other schemes for education loans.

- Education Information and Status: The development of educational status of children will be recorded continuously. In this case, we can monitor the population levels of education in general. This is useful as the basis for policy decisions, including monitoring the level of the national human resources, facing the AEC. Here we can also monitor the levels of skill or expertise of Indonesian human resources and can use it as the basis for the development of priority services sector.

- Access to various services: Many types of services may or may only be accessed by people every day. Access to various services requires identity proof or place of residence or residents' status. With the single and national identity, such variety of services can be obtained only by proving a single identity, for instance in the library, for boat crossing services, trains, and airplanes.

- Access to Financial \& Banking Services: When people begin to enter adulthood, they will have the need to gain access to financial services. Someone will start to encounter borrowings including business loans. Someone also begins to require a means of saving money and get paid via bank.

- G2C (Government to Citizen) Services: There are some services provided by the government to the public such as driver's license, Passport, Voter Cards, and others.

- Access to Employment \& Business Opportunities: National identity helps people to access employment opportunities in the government or private sectors.
National identity will provide authentication and proof of authenticity as a resident.

- Old Age Service: services for the elderly are required, among others, to obtain a pension. National Identity can help the elderly easier access in managing pension funds, banking and medical matters, and etc.

Nevertheless, each country still has different views on the nationally-centralized identity. Some country like Australia still has not introduced a system of national identity, while other countries have had it since the beginning such as Spain, Brazil, Pakistan, and Malaysia. There are also some countries that are just starting with their own pros and cons among the people, such as the United States and the United Kingdom.

Large countries like the United States and the United Kingdom started integrating data nationally because there is awareness of the need for security after the terrorist attacks of 11 September 2001; it even then brought up the pros and cons as there is privacy paradox. On the one hand, the country is demanded to increase security, on the other people do not want their privacy to be disturbed by state control. This is exemplified in England by Beynon-Davies in [13], as quoted in Lips, et al. [14] that "A general conviction is that, with the introduction of an ID card, UK citizens are required to trade an element of Reviews their privacy for increased security".

Different reasons exist for developing countries such as Indonesia, Brazil or India. The need for integrated data of identity is necessary to address the issues of public services. National population data integration will help the state manage public services more efficiently and effectively. As an illustration Rajanish and Bajaj in [12] describe the need for national population data system in India as follows:

- The need for a single national ID for a large country like India becomes more crucial than for a host of countries that have already adopted such a system or are in the process of such an exercise. Provision of multiple services to a large population by government and private organizations is a mammoth task and is accompanied by many hurdles. Unique National IDs would help in the better delivery of government services like Public Distribution System, Grameen Yojana, Rozgar Yojana, Self-Employment, banking and investment services, health facilities and different schemes offered by the government. Other benefits which could be derived are a single document with multiple information integrated to strengthen national security and social security for citizens, a useful means for citizens to access multiple government and private services and benefits, and an easier and safe means for entities to offer services, employment, etc.

In India, a national identity system will help facilitate government's very diverse public services. The provision of a variety of public services ranging from education, health insurance, until old age security in a large population is a tough task for a government. For developing countries, the existence of population data integration system will ease such diverse process of public services so as to create security for the community. 
According to Beynon-Davies in [13] a good identification system is essential to ensure that policies are effective. According to Prabhakar, et al., [15] as cited in from [12], the characteristics of a good identification system include:

- Universality of coverage, in which everyone in certain domain or situation must have an identification tool.

- Uniqueness. Each relevant person may only have one identification tool, and there are no two persons or more who have similar identification.

- Permanence. The identification tool cannot change or be changed without any authority.

- Indispensability. The identification tool must be capable of using any time.

- Exclusivity. There is no other form of identification that is required or used.

To create a good identification system in the modern era, an identification system of residents' formal identity has been transformed from merely an identity card (ID) up to electronic-based one. According to Castro in [16], the use of electronic ID system is also beneficial for the business world and government-including digital economy in the field of trade, enabling e-government services, and enhancing security for online transactions. With the use of electronic communications, it can save costs, including shortening the travel time to the government offices or public notary. Similarly, in the business world, it gives the advantage of being able to interact securely with government via online for activities such as paying taxes or making of a license.

In connection with the implementation of the e-ID system, Castro [16] explained that the Government becomes capable of offering a better innovative public service that requires authentication. E-ID system eliminates the need to write data in paper form, helping to reduce errors and processing-time. In the end, the use of e-ID system will be able to improve the security of online transactions and help prevent fraud and identity theft. The e-ID program can encourage many countries to facilitate service to the community. The use of e-ID, particularly in facilitating various types of egovernment services, encourages the government to streamline its various services.

A number of European countries have implemented the system of national identity in the form of e-ID, including Belgium in 2004, Finland in 1999, Estonia in 2002 and Italy in 2002 [17]. Belgium, for example, since 2004, has been providing e-ID card service called BelPIC as the largest e-ID system in Europe. This service allows online access rights, in which authentication is achieved through the identification certificate stored in BelPIC. In the meantime, Spain and Portugal implement the function of e-ID on the national ID card with the scheme of public key infrastructure in 2006. The different schemes are also applied such as password-based systems and Attribute-Based Credentials solutions $(\mathrm{ABC})$ in a number of other European countries in the electronic national identity cards [18]. Some other EU countries provide exceptions to the right of access and the type of access granted to the data subject, depending on the specific context [17], [18].

Sweden began implementing NIDEL card in October 2005. This card serves as proof of identity and citizenship, in which the access rights may not be available in some extraordinary circumstances. This is because the existence of
Secrecy Act that regulates the information, allowing it not to be disclosed to the data subject.

Another European country, Lithuania, since January 2009 has been implementing a roll-out of national biometric e-ID card. The card is intended to provide more secure ID cards and facilitate efficient border controls. The ID card contains a digital certificate that is used by individuals on a computer with a card reader for more secure online transactions, such as authentication for online services or electronic document signatures [17].

In the neighboring country of Malaysia, national identity card system has been in operation since 1949. However, it was only in September 2001 that the Malaysian Government launched a smart card ID known as 'MyKad', which combines several single applications in the card with some personal information of the cardholder.

In Indonesia to obtain data on population, a census must be conducted; it was first performed around 1930 by the Dutch government. Based on the note of Central Bureau of Statistics (BPS), the population census has been carried out 5 (five times) after independence, namely in 1961, 1971, 1980, 1990, 2000, and 2010. Previously, until 2000, population census is considered as the only most valid registration system, thus the only source of population data that could give an idea of the Indonesian population situation comprehensively. The situation, however, has now changed, although a little bit behind other countries that have disciplined their population data. Since the publication of Law No. 23 of 2006, as amended by Law No. 24 of 2013 concerning Population Administration, Indonesia has established a population database based on SIAK and NIK [19] to update population data through verification and validation activities.

After the enactment of the Government Regulation No. 37 of 2007 [20] on the implementation of Law No. 23 of 2006, and Presidential Decree Number 25 of 2008 [21] on the Terms and Procedures for Population and Civil Registration, the only most valid registration system is through the Population Administration System (SAK) for SAK is a series of planning and controlling activities on the issuance of documents and demographic data through registration, civil registration, demographic and administrative information management, as well as the utilization of the results for public services and public sector development.

As for Indonesia, in 2009 it has launched KTP-el (e-ID Card) program as national identity cards by making 6 Districts/Cities as pilot projects. e-ID Card is a demographic document that contains security or controlling systems both in terms of administration or information technology, based on national population database. Residents are only allowed to have one ID card listed as Personal Identification Number (NIK). NIK is a single identity of each resident and is valid for life.

\section{RESULTS AND DISCUSSION}

\section{A. The Portrayal of E-Id Card Public Service Pattern in Indonesia}

In general, based on desk study and interviews, a description of the national population data integration strategy is obtained. The national strategy to get valid and 
updated data is to manage a Population Administration Information System (SIAK) to facilitate the Population Record and Civil Registration services carried out by the Department of Population and Civil Registration at districts/cities throughout Indonesia. This is based on the Law of the Republic of Indonesia Number 23 Year 2006 concerning the Population Administration as amended by Law Number 24 Year 2013, in Article 82, that the Minister of Home Affairs is mandated to carry out the management of Population Administration information through the development of SIAK.

The formation of a nationwide Population Database is derived from the integration of the daily service of Population and Civil Registration using SIAK throughout the district/city through the Department of Population and Civil Registration (DISDUKCAPIL). The results of these services are further consolidated and integrated with the nationwide e-ID cards recording results to be made as valid data; thus avoided from the tendency of double data or data anomalies.

The sources of data available to be consolidated are 1) SIAK data, resulting from the daily services of Population and Civil Registry; and 2) e-ID Cards data. Both data have different yet complementary characteristics. SIAK records all demographic data without biometric, whereas e-ID Cards record the data of residents mandatory to have biometric ID cards. The consolidation and clearing process of the Demographic Data are based on the Circular of the Minister of Home Affairs No. 470/735/SJ, dated February 13, 2013, regarding the Presentation and Utilization of Demographic Data, addressed to Governors and Regents/Mayors throughout Indonesia, which basically set that:

- To create an accurate National Demographic Database, (central, provincial and district/municipal) two most basic activities are required, namely: daily service of Population and Civil Registry, including e-ID Cards recording, registered in the Population Database at districts/cities, implemented by the Department of Population and Civil Registration;

- To avoid differences of Demographic data, the regular data provided by the Ministry of Home Affairs, the provincial government, and district/municipal government is Demographic Data published periodically per semester: for the first half of semester is published on June 30, and the second half is published on December 31.

- For the special/specific purposes, the provincial and/or the district/city governments may request the Ministry of Home Affairs to publish demographic data exclusively, outside of the publishing agenda per semester.

After the demographic data from districts/cities are consolidated and cleaned up by the Ministry of Home Affairs, several double data (recording more than once) are found. This has become a very important process in the integration of the national population data and e-ID Cards printing across the archipelago.

\section{B. The Chronology of E-Id Cards Public Service} Implementation In Indonesia

Electronic National Identity Card (e-KTP) is a digitization form of residents'personal identity through electronic identification (e-ID) or smart card ID, first created in 1970. The Unitary State of the Republic of Indonesia itself only has a legal basis for e-ID Cards in 2009, i.e. the Presidential Decree Number 26 Year 2009 on the Implementation of NIK-Based ID Cards Nationally, making 6 districts/cities as pilot projects. Furthermore, in 2011 the program began to be applied massively in 197 districts/cities; and in 2012 it was implemented in 300 districts/cities. The activities were organized as the central government's program (in this case the Directorate General of Population and Civil Registration of the Ministry of Home Affairs) where the data recording of residents were conducted in each sub-district, connected (online) to the Centre. This means that the results of data recording are collected in the Center, and the personalization/printing of the e-ID Cards are carried out by the Centre in this regard PNRI. Once the massive e-ID card program was finished, in 2014 the regular e-ID Cards started to be implemented, in which the regular data recording is still conducted in every sub-district, connected (on-line) with the Center for verification. Once completed, the printing is conducted by the Department of Population and Civil Registration at the district/city.

In the process of implementation, the national population data integration has come a long way. The implementation began with the construction of Population Administration Information System (Sistem Informasi Administrasi Kependudukan/SIAK) to the application of electronic National Identity Card (KTP-el) massively for 172 million compulsory e-ID cards. The implementation process took nearly a decade.

Chronologically, the implementation of demographic data integration through KTP-el can be clarified as follows:

- SIAK was initiated in 2004 with the 400 districts/cities throughout Indonesia. Yet up to 2006, only 30 districts/cities had implemented SIAK. This is due to several constraints, among others: Most district/municipal governments had generally not prioritized the development of SIAK, preferring to build buildings or other facilities; some areas in the eastern region is plagued by electrical problems of insufficient voltage, so that the electricity during the day often outages; and some areas are also experiencing problems of data communication network system, so it cannot carry out on-line SIAK.

- Based on these constraints, the policy strategy adopted by the Ministry of Home Affairs is to provide facilitation to the district/city in the form of SIAK hardware, gradually starting from 2006 (111 districts/cities) up to 2008, through the State Budget. The facilitation is rendered to districts/municipal governments that do not have the SIAK device.

- In 2006, the government passed Law No. 23 of 2006 concerning Population Administration, the logical consequence of which the state must provide protection and recognition of the legal status of the residents on their demographic and important events in a more optimal way. One of the State recognitions 
is by providing an electronic identity card to residents. In 2013, the government revised the law with the enactment of Law No. 24 of 2013.

- To apply KTP-el massively in 2010, the Steering Committee of NIK Publishing and the Implementation of NIK-based Identity Cards throughout Indonesia was formed through Presidential Decree No. 10 of 2010, chaired by the Coordinating Minister for Political, Law, and Security. In the same year, the updating of demographic data in all districts/cities was conducted using state budget through de-concentration funds, using the SOP of Matching, Research, and Verification of Form F-1.01. The publishing of NIK was targeted to 329 districts/cities.

- In 2011 the publication of Personal Identification Number (NIK) had been conducted in 168 districts/cities and the application of e-ID Cards has been successfully carried out in 197 districts/cities. In the same year, the Expert Team of the Directorate General of Population and Civil Registration, Ministry of Home Affairs was established. Then in 2012 the Implementation team of Electronic Identity Card in the Directorate General of Population and Civil Registration was formed. The team consisted of 15 people of Steering Team, 588 people of Supervision Team 588, 66 people of Monitoring Team.

- In 2011, the central government began to do socialization to the apparatus of the central, provincial, and district/municipal governments through the National Coordination Meeting by inviting the Governors, Heads of the Provincial Parliament, Regents/Mayors, Heads of the District/Municipal Parliament, and the Heads of Population and Civil Registration Offices in District/cities throughout Indonesia. The socialization is also done through the print and electronic media, billboards, banners, leaflets, and booklets.

- At the same time, the government conducted an auction on the implementation of the policy of e-ID Card. The preparation of Technical Specifications was conducted by involving a team from 15 Ministries/Institutions, whose results are then stipulated by the Minister of Home Affairs. In the auction process, the Committee is assisted by a Technical Team consisting of representatives from BPPT, ITB, LSN, and the Ministry of Home Affairs, accompanied by LKPP, BPKP team, and the results were audited by BPKP.

- To speed up the process of e-ID Card implementation nationally, in 2011 a supervisory team was also formed by the Decree of the Minister of Home Affairs No. 471. 130.5-525, on the Formation of Supervisory Team for the Implementation of e-ID Card at 197 districts/cities at the Directorate General of Population and Civil Registration, which amounted to 446 people, consisting of representatives from the Ministry of Home Affairs, BPPT, ITB, LSN, BPKP, Police, and APTIKOM. The team then held a National Coordination Meeting (Rakornas) on October 17-18, 2011 and strove to maximize the function of Supervisory Team in guarding and ensuring the implementation of Rakornas agreements in order to achieve the targets in 2011 and 2012.

- The signing of Agreement/Contract was conducted on July 1, 2011, with a third party as the preferred bidder, in this case, the consortium. The Consortium consisted of PT Sucofindo, conducting Technical Training to the operator who will make the recording of e-ID Card in each district (2,348 districts) and Technical Assistance for operators in each district/city, using the State Budget; PT Quadra, responsible for the provision of Hardware and Software for the recording e-ID Card, using the State Budget; Indosat, having a role in providing Data Communication Networks; and PT PNRI, preparing the blank form and printing the e-ID cards, and sending the results to each district, using the State Budget.

- Given the limited time of the e-ID Card implementation, at the end of 2011, the Minister of Home Affairs issued a Minister of Home Affairs Circular No. 471.13/5266/SJ, dated December 30, 2011, regarding the Dispensation of Publishing e-ID Card Services Massively, disseminated to Governors and Regents/Mayors throughout Indonesia. Dispensation was given specifically to the residents living outside the domicile of origin. This happens considering many residents (among others: students, employees of private sector, traders), due to their education or work, already live outside the domicile of origin without going through the process of moving (not minding Certificate of Moving). To smooth the issuance of e-ID cards massively, such residents are given dispensation of services outside the provisions of Article 16 paragraph (2) of Presidential decree No. 25 Year 2008, i.e. not requiring Certificate of Moving from the area of origin.

- The process of dispensation has become one of the important milestones in the integration of the national population data. In this process, additional population data and the Family Card (KK) concerned as a result of the dispensation were distributed to each administrative village and put in a database of Automatic Fingerprint Identification System (AFIS) to be given similar e-ID cards service with those already registered in the previous AFIS database. At the time the residents recorded their e-ID Card, they were altogether asked to sign the Family Card (KK). They were given a new KK or inserted into the existing KK at the new address. The residents whose new Family Card have been issued must then be removed from the Population Database at districts/cities of the old domicile (domicile of origin). This dispensation process was initially valid from January 5 until October 31, 2012, but then extended to be valid up to October 31, 2013.

- In 2011, the Government also revised the Presidential decree No. 26 of 2009 as amended by the Presidential decree No. 35 Year 2010 and Presidential Decree No. 67 of 2011. The fundamental issue amended was the validity of non-electronic ID cards from 31 December to October 31, 2013. 
- In mid-2012, the massive e-ID Card recording had been conducted in 197 districts/cities. The target was achieved on April 30, 2012. The recording of e-ID Card in the 300 districts/cities for some 172 million compulsory e-ID cards was then subsequently targeted on December 31, 2012.

- Commencing on January 1, 2013, the implementation of regular e-ID Card services in all districts/cities in Indonesia begins. In 2013 the District/City government is also required to be able to complete eID Card recording for residents, compulsory to e-ID cards that have not been recorded. It becomes the responsibility and obligation of the district/city government.

- In 2013, through the Minister of Home Affairs Circular No. 471/1826/SJ, dated April 11, 2013, the entire Government Agencies, Local Government, Banking and Private Institution shall prepare the necessary technical equipment with regard to the implementation of e-ID Card, including card reader as mandated by Article 10C paragraph (1) and (2) of Presidential Decree No. 67 Year 2011. Each institution must facilitate all work/business units or other names in the ranks that provide services to the community to provide card Reader within a short period.

- In term of demand, by the end of 2013, the biometric recording of residents' data (compulsory to have e-ID cards) has reached merely about 180 million people and the issuance of ID card printing has reached only about 145 million e-cards. Thus, in 2014 the overall population of compulsory e-ID cards has not all had the e-ID Cards; there are still some residents (about 35 million Indonesian, or 19 percent) still having nonelectronic ID cards.

- In fact, the liability to provide e-ID Card for all citizens is difficult to do, thus the Presidential Decree No. 112 of 2013 [22] was issued, stipulating among other things that the Non-Electronics ID (regular ID cards), which previously expired on December 31, 2013, was extended until December 31, 2014, with considerations:

- Until the end of 2013, of the 191 million people compulsory to have an e-ID Card, there are 19 million residents who have not possibly obtained e-ID Card until the end of 2013;

- The implementation of e-ID Card printing in 2014 was handed over to the district/city as mandated by Article 10 of the Presidential Decree Number 112 of 2013, while the budget for e-ID Card printing is charged to the Amended State Budget (APBN-P) 2014, predicted to be available in mid2014;

- If the validity period of non-electronic ID Card was not extended, then the amount of about 19 million residents shall not have identity cards, since the Non-Electronic one is no longer valid, while the electronic one has not been possible to obtainment;

- Based on this condition, the Presidential Decree No. 112 of 2013 on the fourth amendment of Presidential
Decree No. 26 of 2009 confirms that in order to Implement NIK-based national e-ID cards, the validity of non-electronic identity cards in Indonesia only lasts until December 31, 2014. Therefore per the date of January 1, 2015, all Indonesian citizens must already use e-ID Cards as the basis to get public services, such as obtaining a driving license, passport, a Certificate Land rights, insurance, and etc.

In fact, based on the evaluation study conducted by Soemartono [23] in Jakarta, in term of supply, the implementation of e-ID card program has not optimally succeeded. Some of the obstacles are its failure to measure NIK updates, hence the data validation is lacking. The implementation period is notably short, starting in midSeptember 2011 until the end of 2012, with the number of people compulsory to have e-ID cards 172 million. Hence public services should be given for the data recording up to the printing/personalization of e-ID cards, having implication in the less optimal management.

The implementation of e-ID Cards program tends only to meet short-term targets, namely, the fulfillment of voters list (DPT) data both for the 2014 election and 2019 election. This is asserted in the statement of the Minister of Home Affairs, as quoted by in [24], stating that the government in January 2015 has proposed an additional budget to continue the e-ID cards project with a target that it can be used as the basis of the voters list in the upcoming 2019 elections.

The new policy that sets the population administration shall affect the implementation of its public services. In fact, since 2014 the entire public services of population administration, including the issuance of demographic document of e-ID Cards, are given to the implementing agencies at the district/city. This changes the model and pattern of public services not only in population administration sector but also in other sectors that require demographic data as the basis of service delivery.

Based on the previous study regarding the evaluation of eID Cards in Bandung district [25] basically, people believe that e-ID Card as a single identifier system will be beneficial to the provision of public services such as social security, hospital database, and so on. Nevertheless without the efforts of policy sector to accelerate the integration and synchronization of data existing in each sector, including Health BPJS, then this trust will be difficult to maintain. On the other hand, Health BPJS must meet the target of the entire residents; while the e-ID Cards only record people with NIK of mature age (> 17 years). This will obviously cause problems if the population administration is not followed by solutions to problems through policy approach.

In terms of policy actors, there are institutional problems that become obstacles, including the understanding of the regional apparatuses (Office of Population and Civil Registration/Dukcapil) regarding the maintenance of e-ID card database that needs to be upgraded and whose service is still ineffective. In addition, there is no synergy between stakeholders in the field, both at the levels of provincial and municipal government to the lowest level of administrative village [25]. It is becoming increasingly difficult to overcome because since 2014 all public services of population administration, including the issuance of 
demographic document of e-ID Cards are given to the implementing agencies at the district/city.

\section{The Current Demographic Data Administration in Makassar}

Makassar is a municipality as well as the capital of South Sulawesi province. Makassar has a strategic position due to its location at the crossroads of traffic from the south and the north in the provinces of Sulawesi; from the western and eastern regions of Indonesia; and from northern to southern regions of Indonesia. This has an impact on the high economic attractiveness of the city of Makassar. Economic attraction of Makassar obviously has an impact on various population problems, both the high mobility of the population (visible from incoming population migration) to the issue of quantity, quality, carrying capacity and the receiving capacity of Makassar in the future. Therefore, the population administration services become very important for Makassar.

In the first half of 2015, the number of residents in Makassar reached 1,652,970 million inhabitants, 1,190,924 of whom are compulsory to e-ID cards (above the age of seventeen). The total area ofMakassar is approximately $175.77 \mathrm{~km} 2$ of land area, including 11 islands in the Strait of Makassar plus waters area of approximately $100 \mathrm{~km}^{2}$. The number of sub-districts in Makassar is as many as 14 subdistricts and 143 administrative villages. Among the subdistricts, seven are bordering with coasts, namely Tamalate, Mariso, Wajo, Ujung Tanah, Tallo, Tamalanrea and Biringkanaya sub-districts. In this city, there are various ethnic tribes such as Makassar, Bugis, Toraja, and Mandar. In this city, there is also a sizable Chinese community. Today, the city of Makassar has been a trading center for eastern Indonesia. The centers of commerce from traditional markets, wholesale markets, to modern shopping malls are growing rapidly. As a major contributor, the sector is able to absorb the labor market amounted to 34.24 percent of the 904,644 working-age population.

Services of Population and Civil Registration in Makassar are conducted based on Makassar Regional Regulation No. 9 of 2009 on the Implementation of Population Administration and Civil Records, and Makassar Mayor Regulation No. 1 of 2010 concerning Terms and Procedure of Population and Civil Registration. In addition, the Government of Makassar has also deleted the levies on population administration services through Makassar Mayor Regulation No. 14 Year 2015 concerning the Elimination of Levies for Population Administration and Civil Record Services. The population administration Services in Makassar also refer to the Standard Operating Procedures of the Population Administration. In providing services of Population and Civil Registration, Makassar's Office of Population and Civil Registration uses forms and books, according to Minister of Home Affairs Regulation No. 19 Year 2010 on Forms and Books Used in the Population and Civil Registration.

However, some Civil Registrations in Makassar still have not been conducted using SIAK, i.e.: Birth and Mortality Records; Reporting of Overseas Marriage Registration outside the territory of the Republic of Indonesia (RI) for Indonesian citizen; Reporting of Overseas Divorce
Registration outside the territory of RI for Indonesian citizen; Reporting of Overseas Mortality Records outside the territory of RI for residents; Reporting of Alien Residents Adoption Records outside the territory of RI; and the Registration of Citizenship Status Change. This certainly has an impact on the integration of demographic data for the validation process will take longer.

The outline of Makassar demographic data in the first semester of 2015, based on the nationwide integration result of demographic data is as follows:

- The initial SIAK data =1,807,847 people;

- Data anomalies (non-standard data) = 5,924 people;

- Demographics missing (NIK is available in e-ID Cards data yet unavailable in SIAK data) $=9,269$ people;

- Six element double data (similar full name, sex, birthdate, place of birth, mother's full name, father's full name) $=6,226$ people;

- Five element double data (similar full name, sex, birth-date, place of birth, mother's full name) $=19,694$ people;

- Four element double data (similar full name, sex, birth-date, place of birth) $=33,033$ people;

- Clean data in the first semester of $2015=1,652,970$ people.

With the consolidation and cleaning of Makassar demographic data by the Ministry of the Home Affairs, there are 44,877 inhabitants whose data are inaccurate. The process of integration has also been hampered by a large number of Makassar residents who have not been recorded. Based on the data from the Directorate General of Population and Civil Registration of the Ministry of Home Affairs, in the first half of 2015, the number of residents in Makassar required to have ID cards is $1,190,924$ people of a total $1,652,970$ people. Of the number of compulsory ID cards, those who have recorded are merely 786,284 inhabitants; while the rest who have not recorded are 413,640 inhabitants.

\section{The Present Dynamics of Problems of E-Id Card Services in Makassar}

Based on the study result in the field and observations conducted by researchers, there are various problems occurring in the field, especially in the implementation of the integration of demographic data in Makassar. One of the main problems today is still the slackness in the printing process of e-ID Cards. There are still a lot of people who have done e-ID Cards recording yet have not received its print for too long, causing complaints in the community.

Basically, the authority of e-ID card regular recording has been in the hands of the region, particularly in the Office of Population and Civil Registration at Districts/Cities. In fact, there are limitations both the institution (HR, the recording process, and infrastructure) as well as the community itself. More clearly they are described as follows:

1) Institutional Problem in The Region for e-ID Cards Printing Service: In line with the national interest to integrate demographic data, the central government has been playing a full role, especially in encouraging e-ID Cards massively. However, in time the centralization of e-ID Cards 
policy implementation encountered an obstacle for not having met the target of the entire resident compulsory to ID cards. It is due to, among others, the limitations of the central government in implementing e-ID Cards policy that has a very broad scope. On the other hand, the lengthy process up to the central level obviously takes time from the recording process to the printing. It was later improved by restoring the local authority in terms of recording and printing the card on a regular basis.

The increased authority is the result of the new policy, as stated by the head of DISDUKCAPIL of Makassar: "e-ID card printing was previously carried out by the Director General of Adminduk. Nevertheless, with the new policy, the printing of e-ID card is now under the authority of district/city government through Dukcapil".

However, in reality, the region has many limitations. Based on field observations, interviews, and FGD, the institutional constraints in the region in the e-ID Card service include the lack of human resources, equipment, and distribution. This readiness determines the extent to which institutions in the region are able to carry out their duties:

The regional institution also has weakness in terms of human resources; this is, of course, contradictory with the decentralized authority for e-ID cards recording and printing given by the center to the regions. This contradiction is in line with what is stated by Lipsky in Hill [26]in which he explains that in carrying out operational policies, the streetlevel bureaucrat becomes a kind of public personae of the service organization because they often run into contradictions. On one hand, the services should be provided with full satisfaction and responsibility, on the other hand, services are hampered by regulatory norms of the organization and limited resources, so that services become inflexible.

- Supposedly, the decentralization Human Resource Barrier. In fact, there is a lack of human resources for Population Registry. There is a lack of Registration Officers who help the village chief and the DISDUKCAPIL to provide services to Indonesian residents who encounter demographic and important events. Currently, only one (1) person is in charge in every administrative village, hence causing the population and civil registration services at the village level not optimal.

- Device Barrier. It is considered to be severely hampered; there are only two units of e-ID Cards printing device at the Dukcapil. This is not suitable for the needs of residents whose data are to be recorded at the 14 sub-districts in Makassar. Supposedly they are supplied 14 units (1 unit for 1 Subdistrict), adjusted to the population of Makassar. Therefore, in 2015, Makassar has added two (2) units of e-ID Cards printing devices through Regional Budget (APBD).

- Distribution and Networks Barrier. Distribution and telecommunications are obstacles for ID cards printing. The distribution of blank ID card form was only distributed by the Central Government at the end of 2014; hence the printing/personalization of e-ID cards can only be done in 2015 . In addition to the issue of device limitation, there is also the issue of communication networks limitation. The data recording at the sub-district must be on-line to the Centre (Ministry of Home Affairs) at Merdeka Utara Street. The printing/personalization of e-ID Cards is carried out by the DISDUKCAPIL, verified by the Central Government, in this case, the Directorate General of Population and Civil Registration, Ministry of Home Affairs. It is very dependent on the data communication network that is sometimes disconnected, thus must wait for network connectivity for some time, even days to resume the e-ID Cards printing process.

The regional institution also has weakness in terms of human resources; this is, of course, contradictory with the decentralized authority for e-ID cards recording and printing given by the center to the regions. This contradiction is in line with what is stated by Lipsky in Hill [26]in which he explains that in carrying out operational policies, the streetlevel bureaucrat becomes a kind of public personae of the service organization because they often run into contradictions. On one hand, the services should be provided with full satisfaction and responsibility, on the other hand, services are hampered by regulatory norms of the organization and limited resources, so that services become inflexible.

Supposedly, the decentralization of authority for recording and printing gives a significant impact on increasing the number of people recorded and printed. According to Ambar [4], decentralization is assumed to be able to improve the allocative and productive efficiency of service. Current conditions indicate that in the future the decentralization given must be able to encourage efficiency of e-ID Card service to run more productively.

Activities of the regional institution in giving e-ID Card service are also closely tied to the strength of local bureaucracy in implementing a policy. The bureaucracy itself has a strong closeness with the interests of each institution involved. It is stated that "The public bureaucratic structure is marked by the behavior of interest group, fragmentation of conflict, and competition." In terms of demographic data integration, clearly, the problem of fragmentation of central and local interests becomes very apparent in the process of implementation.

In this context, Makassar has an organizational interest, where the smart-card program becomes a priority of the current Mayor. According to the Mayor of Makassar, Ramdhan Pomanto: "This [smart] card can also store personal data, indicated on the electronic ID card. Just by attaching it to an Android-operating-based smart phone, equipped with a special application, all data on the phone display, such as e-ID Card, BPJS, TIN, and the United Nations, will emerge. In this card, there is also a report or a history of illness owned by the cardholder. There are 125 types of diseases that can be accommodated in the card." Such statement clearly indicates that the concept of the smart card itself depends on the existence of e-ID Cards.

The e-ID Cards process is basically a form of egovernment concept implementation, thus must be supported by good HR and network infrastructure. With the persistence of the human resources and infrastructure constraints, the obstacles will always happen. This is as stated by Silalahi et al. [27] in which one of the constraints in the implementation 
of e-government in Indonesia is the unavailability of adequate human resources (HR) for managing e-Government and information-network infrastructure that have not been evenly distributed across the regions.

Organizationally speaking, the implementation of e-ID Cards public services is a form of e-Government implementation in the Indonesian bureaucracy. The barriers occurring in the integration of demographic data itself are common obstacles, prevalent in the implementation of eGovernment. Therefore, these obstacles should be a motivation to encourage accountability of Makassar government to apply the concept of e-Government in the bureaucracy.

Without efforts to accelerate the integration of demographic data through e-ID cards, then it is difficult to implement the policy of integrated smart-card public services, considering the personal data of residents of Makassar will be difficult to collect. Therefore, the success of the implementation of e-ID cards in Makassar indicates the success of Makassar in developing the concept of Smart City in the future, through the implementation of smart cards. It will also parse the fragmentation that had occurred; hence the interest of the central government to integrate demographic data through the e-ID Cards can go hand in hand with the concept of Smart Card promoted by the Mayor of Makassar.

2) The Weak Public Understanding of The Urgency of Demographic Data: George C. Edwards asserts: The main requirement for the effectiveness of policy implementation is those who apply the decisions must know what they should do. In this case, the interpretation of each of the stakeholder, including the community, is important to note. In the context of demographic data integration through e-ID Cards, public understanding of the urgency e-ID Cards is still very low. This is evident from the low interest of the community to register their identity. This is as stated by the Secretary of DISDUKCAPIL: "The many Makassar residents who have not had e-ID cards is due to low public awareness to make a demographic identity..... it is only at the period of new student admittance, that the registration of birth certificate is commonly increasing."

In other words, people still do not consider important the existence of e-ID Cards. People only register it when they are demanded (to register to school). As a result, the integration process is also hampered by the many Makassar residents who have not been recorded. Based on the data from the Directorate General of Population and Civil Registration, the Ministry of Home Affairs, at the first half of 2015 the number of residents in Makassar required to have e-ID cards is $1,190,924$ people of the total $1,652,970$ inhabitants, and only 786,284 people have been recorded. Residents without e-ID cards are spread across a number of sub-districts in Makassar, most of them from Biringkanaya sun-district. To optimize the e-ID Card service, DISDUKCAPIL performs legal operation going straight to the field to record citizens and provide services of demographic documents, such as the Family Card (KK), birth certificate, and e-ID Card.

According to the head of DISDUKCAPIL at Makassar, the reporting of demographic incidents and important events such as death is still currently low. This results in the invalidity of demographic data in Makassar. The head of RT (neighbourhood) must be active, reporting to DISDUKCAPIL, yet the reported data cannot be used to process the issuance of Certificates of Death. Again, this implies the invalidity of the demographic Data. Updated demographic data from Population and Civil Registration service using SIAK sent by the DISDUKCAPIL at districts/cities need to be consolidated and cleaned, depending on the outcome of reporting. Demographic data can be considered valid/updated if the demographic incidence or important events are reported by residents in time, so that recorded in the Population Database at districts/Cities. Due to the low reporting, there are several issues, among others:

- Events of death are still minimally recorded. Regarding Registration of Death, based on Law Number 23 Year 2006 concerning Population Administration as amended by Law No. 24 Year 2013 on Article 44 paragraph (1), that every death must be reported by the head of Neighborhood (RT), or other names in the domicile to the Implementing agency, in this case the local Department of Population and Civil Registration (DISDUKCAPIL) no later than 30 (thirty) days from the date of the death. In this regard the DISDUKCAPIL of Makassar has sent forms to be filled by the RT; nevertheless, the result is they only get the number of Death yet cannot process it for the issuance of a death certificate.

- Besides the issue of death, there is also the issue of marriage registration. There are many residents who are married unofficially (nikah siri) without official marriage books; thus in registering a birth certificate for their children, they can only be recorded as the children of the mother (without mentioning the father). In this regard, the child only has a legal relationship with the mother only; thus incapable of inheriting rights from his/her biological father. Regarding the requirement of two witnesses in the reporting of child birth, it is still considered burdensome; similarly with the registration fee, to bring it up to the Office of Population and Civil Registration.

- The issue of residents relocation or transfer between districts/cities and between provinces that are not reported to DISDUKCAPIL in both the area of origin and destination becomes a serious problem. In Election 2014, many residents are found to have a domicile in an area without having an identity in the region. The documents brought from the area of origin are even outdated demographic documents (red KK, and yellow ID cards); nevertheless, the residents have the right to vote because it is the mandate of the Electoral Law. Of course, the residents were eventually given a Certificate of Domicile by the local village chief as the basis for the right to vote in a general election.

To overcome the lack of understanding, the municipal government has done a lot of activities. Related to the issue of reporting a death, given the concern for residents in possession of a death certificate is still very low, the strategy undertaken by the Government of Makassar in this case the 
Department of Population and Civil Registration of Makassar are: 1) Proposing to the Regional Personnel Agency (BKD) to make a death certificate as one of the requirements for the Health Insurance claim for civil servants; and 2) Propose to Working Unit of Cemeteries to make death certificate as one of the requirements for residents to renovate the tomb of their family.

\section{E. The Implementation of NPS Paradigm In The E-Id Card Public Service In Makassar}

To promote the e-ID Card public service, Makassar municipal government has also directly approached the public. This is as stated by the Secretary of DISDUKCAPIL: "In order to optimize the e-ID card service, we perform operations with the judicial records straight down to the citizens and provide services of demographic documents, such as the Family Card (KK), birth certificate and e-ID card. The major target of this operation is a certain region, such as in the area of the marginally defected. It simultaneously records all data of beggars, both elderly and children".

Through a direct approach to the community, the Municipal Government has conducted socialization and data collection at once. The proactive process is an important and effective way to ensure the population data integration process is going well. A similar process is done to encourage awareness of citizens on the islands, as stated by the secretary of Dukcapil: "my experience, while recently doing operations in the Kodingareang Island, Ujung Tanah subdistrict, we found that the majority of residents do not have citizenship documents on the grounds of the distance from the island to the mainland. Yesterday we published nearly 1,000 birth certificates, including e-ID card. The next plan we go to Barang Lompo Island."

The direct involvement of communities in e-ID Card public service is particularly important to raise awareness of the urgency of demographic data including the e-ID card ownership. Therefore, proactive approach undertaken by the City Government of Makassar is a form of excellent public services, prioritizing services directly to the public. In this context, Makassar Government, particularly local DISDUKCAPIL, has embraced the spirit of NPS paradigm. NPS is a paradigm of excellent public services based on community participation in all stages of implementation [28]. This paradigm shift is important and is happening in Indonesia. According to Nuriyanto [28], the development of civil society movements are in the areas of governance is also applied in the form of participatory governance (public participation in governance). This also has a direct impact on the paradigm shift in the public service, namely the emergence of the new paradigm of public service (NPS).

In terms of NPS paradigm, Bourgon (2007) as cited by the UNDP (2015) argues that government should "[use] the concept of democratic citizenship to open up fresh perspectives, where the role of public administrators is not confined to responding to the demands of users or carrying out orders. Her proposed new approach to public administration contains four elements: Building collaborative relationships with citizens and groups of citizens; Encouraging shared responsibilities; Disseminating information to elevate public discourse and to foster a shared understanding of public issues; Seeking opportunities to involve citizens in government activities." Referring to the opinion of Bourgon, the paradigm of NPS is built by strong elements, capable of binding people voluntarily, and is responsible for the functions of public service. The government itself must be able to be open and proactive in encouraging the involvement of the community. This effort has been undertaken by the City Government of Makassar who proactively "pick up the ball".

The fact is many residents of Makassar still reside in the remote area. The region is difficult to reach and far from Makassar, namely the village in the island and suburbs: 1) Biringkanaya sub-district; 2) Mangala sub-district; 3) Ujung Tanah sub-district; 4) Tamalete sub-district; 5) Tallo subdistrict, and 6) Tamalanrea sub-district. This has been the concern of Makassar government to provide mobile services, incorporating SIAK devices and e-ID Cards printing devices, thus providing convenience for residents who live in the region to obtain demographic documents. In 2015 there were already 14 times mobile services. It is probable that the population who have not yet conducted data recording and receive e-ID Cards reside in this area.

This suggests that NPS paradigm has been well applied in order to encourage the achievement of a common understanding of the community in interpreting the policy of population data integration. NPS paradigm has been applied through a direct approach in the form of pro-active operation ("pick up the ball" effort). It has proven effective in promoting the ownership of citizenship documents in a region whose area is difficult to reach from the city of Makassar.

\section{CONCLUSIONS}

The Region plays a major role in the success of the public service of population administration in particular e-ID Cards. The ability of local government institution in implementing their authority is very important because basically the authority for regular e-ID card recording has been given to the region, particularly to the Department of Population and Civil Registration at districts/cities. The return of this authority is certainly consistent with the mandate of law No. 23 of 2014 on Regional Government.

In terms of public services, there is a contradiction in which regional organizations also have limitations both in terms of human resources, infrastructure, and distribution tool. Besides the lack of public response to the importance of demographic data is also a problem. This is particularly evident in the study conducted in Makassar. There are two major problems in the e-ID Cards public service in Makassar that can be registered, namely: 1) the regional institution that is still weak both in terms of human resources, equipment, and distribution and 2) the public understanding that is still low and has not been responsive to demographic events.

Reflecting on this study, the local government should be able to move more quickly to encourage the efficiency of eID Card services (Recording and Printing) to be more productive. Eventually, public service can continue to run efficiently in line with the principle of decentralization and the paradigm of NPS. This can be done in at least two steps: to make sure that e-government runs at the local level, and to ensure their proactive efforts of public services, i.e. pick up 
the ball directly in the target communities in need of demographic documents.

\section{ACKNOWLEDGMENT}

This research is supported by Universitas Prof. Dr. Moestopo (Beragama), Jakarta, Indonesia.

\section{REFERENCES}

[1] The Republic of Indonesia. (2006). Law Number 23 Year 2006 concerning Population Administration. Jakarta

[2] The Republic of Indonesia. (2013). Law Number 24 Year 2013 concerning the amendment of Law Number 23 Year 2006 concerning Population Administration. Jakarta

[3] Denhardt, J.V. and Denhardt, R.B. "The New Public Service: Serving Not Steering". In Public Administration Review Nov/Dec 2000 Vol 60 no. 6. Massachusetts: Wiley, 2000.

[4] Ambar, W. "Bekerjanya Desentralisasi pada Pelayanan Publik" in JKAP Volume 11, nomor 1 May 2007. Yogyakarta: MAP UGM, 2007.

[5] Yin R. Case Study Research: Design and Methods (Applied Social Research). Illinois: Sage Publications, 1994.

[6] The Republic of Indonesia. Presidential Decree Number 25 Year 2009 concerning Terms and Procedure of Population and Civil Registration. Jakarta, 2009.

[7] OSCE. Guidelines on Population Registration. Warsaw: OSCE's Office for Democratic Institutions and Human Rights (ODIHR), 2009.

[8] Poulain, M. and Herm, A. "Central Population Registers as a Source of Demographic Statistics in Europe", in Population-E, 68 (2), 2013, 183-212. Paris: French Institute for Demographic Studies, 2013.

[9] UN Department of Economic and Social Affair. Handbooks on Civil Registration and Vital Statistics Systems. New York: United Nations, 2002.

[10] Soemartono, T. and Hendrastuti. Administrasi Kependudukan Berbasis Registrasi. Bandung: Yayasan Bina Profesi Mandiri, 2011.

[11] Clarke, Roger. (1994). Human Identification in Information Systems: Management Challenges and Public Policy Issues. Canberra: Department of Commerce, Australian National University.

[12] Rajanish, D. and Bajaj, R.K. Creation of a National Singlel ID: Challenge \& Opprotunities for India, Ahmadabbad: Indian institute of Management, 2008.

[13] Beynon-Davies, P. Personal Identification in the Information Age: the Case of the National Identity Card in the UK". ECIS 2005 Proceedings. Paper 27. Regensburg, Germany, 2005.

[14] Lips, A.M.B., Taylor, J.A. and Organ, J. (2006). "Identity Management as Public Innovation: Looking Beyond ID Cards and Authentication Systems." In Bekkers, V.J.J.M., van Duivenboden H.P.M. and Thaens, M. (eds) ICT and Public Innovation: Assessing the Modernisation of Public Administration. Amsterdam: IOS Press.
[15] Prabhakar, S., Pankanti, S. \& Jain, A.K. Biometric Recognition: Security and Privacy Concerns, IEEE Security and Privacy Magazine, Vol. 1, No. 2, Pp. 33-42, 2003.

[16] Castro, D. Explaining International Leadership: Electronic Identification System. Washington DC: The Information Technology and Innovation Foundation, September 2011.

[17] Bour, I. Electronic Identities In Europe Overview of E-Id Solutions Connecting Citizens to Public Authorities.Leiden: UL Transaction Security, 2013.

[18] Otjacques, B., Hitzelberger, P.,and Feltz, Fernand. "Identity Management and Data Sharing in the European Union". In Proceedings of the 39th Hawaii International Conference on System Sciences. Kauai, Hawaii, 2006.

[19] The Republic of Indonesia. Minister of Home Affairs Regulation Number 25 year 2011, concerning the Guidelines for the Study, Development, and Management of SIAK, Jakarta, 2011.

[20] The Republic of Indonesia. Government Regulation Number 37 Year 2007 concerning the implementation of Law Number 23 Year 2006 concerning Population Administration. Jakarta, 2007.

[21] State Administration Agency of the Republic of Indonesia. Pengembangan Pelaksanaan Pelayanan Prima; Modul Pendidikan dan Pelatihan Kepemimpinan Tingkat III, Jakarta: Lembaga Administrasi Negara Republik Indonesia, 2008.

[22] The Republic of Indonesia. Presidential Decree Number 112 year 2013 concerning the fourth amendment on the Presidential Decree number 26 year 2009, concerning the Implementation of NIK-based e-ID Cards Nationwide. Jakarta, 2013.

[23] Soemartono, T. "The Dynamic of e-KTP Evaluation Program in DKI Jakarta". Business \& Bureaucracy Journal, Vol 20, No. 2 (2013). Jakarta:

University of Indonesia, Faculty of Social and Political Science, 2013.

[24] www.dukcapil.kemendagri.go.id/detail/proyek-KTP-el-mulaijanuari-dilanjut-mendagri-usul-penambahan-anggaran

[25] Soemartono, T. Evaluasi Program E-KTP Yang Dinamis and Mutakhir (Studi Kasus di Kabupaten Bandung. Bandung: IPDN, 2014.

[26] Lipsky, M. "Street Level Bureaucracy: an Introduction" in Michael Hill (Ed.), The Policy Process: A Reader. New York: HarvesterWheatsheaf, 1993.

[27] Silalahi, M., Napitupulu D., and Patria, G,. "Kajian Konsep and Kondisi e-Government di Indonesia" in Jurnal Penerapan Ilmu-Ilmu Komputer (JUPITER) Vol 1 No 1 year 2015. Jakarta: Universitas Borobudur, 2015.

[28] Nuriyanto. "Rembug Pelayanan Publik (RPM) sebagai Aktualisasi Pelayanan Publik Berlandaskan Demokrasi Pancasila". In Jurnal Konstitusi, Volume 12, Nomor 2, Juni 2015. Jakarta: Constitutional Court, 2015.

[29] UNDP. From Old Public Administration to the New Public Service Implications for Public Sector Reform in Developing Countries. Singapore: UNDP, 2015.S. M. Metev and V. P. Veiko, Laser Assisted Microtechnology, 2nd ed., R. M. Osgood, Jr., Ed. Berlin, Germany: Springer-Verlag, 1998. 